\title{
Efficacy of Rhus coriaria (sumac) juice in reducing muscle pain during aerobic exercise
}

\author{
AH Alghadir ${ }^{1}$, SA Gabr ${ }^{1,2}$ \\ ${ }^{1}$ Department of Rehabilitation Sciences, College of Applied Medical Sciences, King Saud University, \\ Riyadh, Kingdom of Saudi Arabia \\ ${ }^{2}$ Department of Anatomy, Faculty of Medicine, Mansoura University, Mansoura, Egypt
}

Received: September 15, 2014

Accepted: April 22, 2016

\begin{abstract}
The main target of this study was to measure the influence of sumac juice drink on muscle indices and pain during an acute, intense exercise for 30 days. Forty healthy volunteers (15-25 years) were involved in aerobic exercise program for 4 weeks. Participants ingested sumac juice or placebo drink twice daily for 30 days. All participants were subjected for the evaluation of pain and estimation of serum: creatine kinase (CK), lactic acid dehydrogenase (LDH), troponin I, hydroxyproline (hyp), total antioxidant capacity (TAC), and in vitro antioxidant activity of sumac juice using pre-validated visual analog scale, colorimetric and immunoassays. The participants of both groups, placebo and sumac, showed an increment in pain scores both during exercise and post-exercise intervals. However, the sumac juice group showed a significant smaller increase in the pain scores compared to the placebo group. Participants in the sumac juice group were more willing to use the drink in the future. They achieved a higher satisfaction of sumac juice in ameliorating and the reduction of pain. Also, the sumac group showed a significant enhancement in the level of CK, LDH, troponin I, hyp, along with significant increase in serum (TAC) compared to the placebo group. The protective activity of muscle may relate to the antioxidant activity of phenolic component(s) in sumac juice as measured by 1,1-diphenyl-2-picryl-hydrazyl (DPPH) radical scavenging (87.9\%) and $\beta$-carotenelinoleic acid (68.7\%) assays. These data suggest that oral administration of sumac juice may have a beneficial effect on muscle performance among athletes.
\end{abstract}

Keywords: muscle fatigue, Rhus coriaria (sumac), exercise, total antioxidant capacity (TAC), troponin I

\section{Introduction}

Fatigue in response to exercise training may be related to varying abnormalities including neurological and non-neurological causes $(3,39,50)$. Exercise induced muscle fatigue occurred as a result of peripheral muscle contractility during work over time $(18,35)$. Exercise protocols of short and longer duration have been applied to measure muscle fatigue tasks. The large diversity in the nature of these exercises, such as variations in duration, intensity and stimulation frequency, is likely to result in different kinds of muscle fatigue (33, $40,52,54)$. Regular physical exercise with varying intensities can induce diseases, acute inflammation, injuries and chronic muscle fatigue as a result of overtraining syndrome, related to partial toxicity of free radicals produced during physical exercise $(9,34)$. Recently,

Corresponding author: Dr. Sami A. Gabr

Department of Rehabilitation Sciences, CAMS, King Saud University

P.O. Box 10219, Riyadh 11433, Kingdom of Saudi Arabia

Phone: +966 562060018; Fax: +966 14698541; E-mails: nadalab2009@hotmail.com; drGabr14@yahoo.com; sgabr@ksu.edu.sa 
the effect of different exercise interventions on the level of disability and endurance of back muscles, and type 2 diabetes mellitus have been investigated $(22,53)$.

The occurrence and extent of such exercise induced muscle injury is routinely assessed from increased blood levels of muscle proteins and enzymes, as this provides the simplest way of studying the effects of exercise on muscles. The proteins usually measured are creatine kinase (CK), hydroxyproline (hyp), troponin I along with lactic acid dehydrogenase (LDH) activity, generally allow earlier detection of muscle injury as well as supporting the theory of muscle soreness $(37,38,41,45,47,56)$. In previous research reports, it was reported that during competition, most athletes used to take traditional oral nonsteroidal antiinflammatory drugs (NSAIDs) to conquer or ameliorate muscle pain during race $(17,20)$. Based on the harmful side effects exerted by synthetic drugs, there is a high tendency of individuals to use herbal medicines to minimize hazardous effects. Sumac plant as herbal alternative medicine contains antioxidants, flavonoids and hydrolyzable tannins which have antioxidant and anti-inflammatory properties compared to other plants such as blueberry and Tart cherries $(5,11,24,36,43,58)$. So, it is possible that the use of sumac as herbal antioxidant remedy before and during vigorous exercise training might have a protective effect against muscle fatigue, pain and damage (32).

The mechanism by which sumac juice supplementation may reduce exercise-induced muscle damage is not well understood. So, the purpose of this study was to assess the effects of sumac juice drink on muscle pain and fatigue biomarkers among healthy subjects participated in controlled training program for 4 weeks.

\section{Materials and Methods}

\section{Subjects}

Forty healthy students were invited to participate in a randomized, placebo-controlled study. Their age ranged between 15 and 25 years. During the study period, all volunteers were stopped from their normal physical activity (recreational) or any specific training programs. All participants were non-smokers and had no history of abnormal alcohol intake. All subjects with body mass index (BMI) more than $25 \mathrm{~kg} / \mathrm{m}^{2}$, and subjects with ischemic heart disease, or with severe orthopedic problems had been excluded from participating in this study. Body fat of each participant was measured using bioelectrical impedance analysis based body composition analyzer (TBF 105, Tanita Corporation, Tokyo, Japan). Subjects were informed with the risks and benefits of the study before participation. Prior to the experiment, a written informed consent was obtained from each participant and a medical check-up was performed to ensure that they were fit, healthy and had no physical limitations. Dietary information of each participant was obtained from food diaries or by extensive dietary interviews and significantly referred according to reference dietary intakes (RDIs) for physically active people $(2,33)$. All participants were instructed not to change their normal eating habits during the entire period of data collection and to record accurately the amount, type of food and fluid consumed. During the exercise program, the participants were prevented from any antioxidant containing diets to avoid cross contamination that may interfere with the data of the proposed study. Participants' data with possible cross contamination of sumac or placebo drinks were excluded from this study. The experiment was conducted in accordance with the ethical guidelines of the 1975 Declaration of Helsinki, and was reviewed and approved by the ethical committee of Rehabilitation Research Chair (RRC), King Saud University, Riyadh, Kingdom of Saudi Arabia. The participants were 
Table I. The demographics and baseline characteristics of participants

\begin{tabular}{|l|c|c|}
\hline \multicolumn{1}{|c|}{ Variable } & Placebo & Sumac \\
\hline Sample size $(\mathrm{M} / \mathrm{F})$ & $20(16 / 4)$ & $20(18 / 2)$ \\
\hline Age $($ years $)$ & $24.9 \pm 5.1$ & $23.6 \pm 3.5$ \\
\hline Height $(\mathrm{cm})$ & $173.2 \pm 8.5$ & $170.2 \pm 3.7$ \\
\hline Weight $(\mathrm{kg})$ & $71.6 \pm 2.9$ & $68.9 \pm 5.6$ \\
\hline BMI $\left(\mathrm{kg} / \mathrm{m}^{2}\right)$ & $23.9 \pm 2.4$ & $23.8 \pm 2.1$ \\
\hline Body fat $(\%)$ & $20.2 \pm 0.9$ & $22.3 \pm 1.5$ \\
\hline $\mathrm{HbA} 1 \mathrm{c}(\%)$ & $4.1 \pm 0.2$ & $2.6 \pm 1.2$ \\
\hline VO ${ }_{2}$ max $(\mathrm{ml} / \mathrm{kg} \mathrm{min})$ & $65.6 \pm 5.3$ & $63.3 \pm 6.5$ \\
\hline
\end{tabular}

Values are presented as mean \pm SD. No differences were detected between groups for any of the parameters listed $(p>0.05)$. BMI, body mass index

classified into two groups according to the exercise test with or without sumac juice supplementation as shown in Table I.

\section{Preparation of sumac juice}

Rhus coriaria L. fruit (sumac) used in this study was obtained from the local spice shop (Othaim Markets) in Riyadh, Saudi Arabia. A total of $750 \mathrm{~g}$ of sumac fruits was soaked overnight in cold water (1 1), then the fruits were mashed, squeezed several times using hands or masher, and left for $30 \mathrm{~min}$ in water. Actually, more sumac juices will release into the water. Afterward, cheesecloth (old cloth napkin) was used to separate solid parts of sumac leaving a clear, red or brown color juice. Finally, the flavored beverage of sumac juice was then pasteurized and bottled into drinking bottles of $300 \mathrm{ml}$. The concentration of the sumac extract in each bottle is equal to $75 \mathrm{mg} / 100 \mathrm{ml}(225 \mathrm{mg} / 300 \mathrm{ml})$ of the juice. Following the procedure used, the juice was preserved under cooling conditions until reused. Each sumac bottle contains a total of $580 \mathrm{mg}$ of phenolic compounds and $80 \mathrm{mg}$ of anthocyanins expressed as gallic acid and cyanidin-3-glucoside equivalents measured by the methods of Singleton and Rossi (51) and Giusti and Wrolstad (15), respectively. Finally, the diet participants were supplemented with sumac juice in bottles $(300 \mathrm{ml})$ twice daily for 7 days/week.

\section{Placebo}

According to the instructions of the manufacturer, the placebo drink was prepared as previously reported (25), about $2 \mathrm{~g} / \mathrm{l}$ of unsweetened fruit punch soft drink (Kraft Corporation, Rye Brook, NY, USA; ingredients listed: citric acid, salt, calcium phosphate, red 40, artificial flavor, ascorbic acid and blue 1) was dissolved in fresh water.

\section{Exercise training protocol}

Participants were involved in supervised aerobic exercise program using treadmill. The program involved aerobic exercise for 45-60 min seven sessions per week, for 4 weeks. The program was designed in the form of circuit interval training mode. The training intensity of 
each individual was calculated as training heart rate of $65-75 \%$ for moderate intensity according to Karvonen's formula (24).

Assessment of visual analog scale (VAS)

A standard VAS of $100 \mathrm{~mm}$ score was used to evaluate the intensity of the pain among the participants of this study. The assessment of pain scores depends on the validity and reliability of the scale to chronic and acute pains as previously reported in literature (2, 57). Each participant completed the VAS pain scale before exercise (Pre), during exercise (after 2 weeks) and post exercise (after 4 weeks). Also, the level of conviction of individuals in the ability of sumac drinks to relief pain as well as their tendency to use this drink in future were evaluated using short questionnaire and Likert scale as mentioned previously (27).

\section{Studies of the in vitro antioxidant activity}

Sumac extract was dissolved in methanol and the antioxidant activity was measured at different concentrations $(10,50,100,500$ and 1,000 $\mu \mathrm{g} / \mathrm{ml})$ using 1,1-diphenyl-2-picrylhydrazyl (DPPH) free radical scavenging and $\beta$-carotene-linoleic acid assays as previously reported $(4,29)$. The antioxidant activity of the sumac extract depends on radical scavenging ability of the sumac extract against DPPH and $\beta$-carotene-linoleic acid. For DPPH and $\beta$-carotene-linoleic acid reagents, the change in color of DPPH radical and $\beta$-carotenelinoleic acid due to the addition of sumac extracts results from electron transfer mechanism. The change in color of these reagents was measured colorimetrically at $\lambda=517 \mathrm{~nm}$ for DPPH, and at $470 \mathrm{~nm}$ with $15 \mathrm{~min}$ intervals for $\beta$-carotene-linoleic acid. Both ascorbic acid and rutin $(1 \mathrm{mg} / \mathrm{ml})$ were used as a standard for antioxidant activity. The radical scavenging activity and antioxidant activity were calculated from the following equations:

$$
\begin{aligned}
& \% \text { radical scavenging activity }=\frac{\mathrm{Abs}_{\text {control }}-\mathrm{Abs}_{\text {sample }}}{\mathrm{Abs}_{\mathrm{control}}} \times 100 \\
& \% \text { antioxidant activity }=\left(\mathrm{Abs}_{0}-\mathrm{Abs}_{t}\right) /\left(\mathrm{Abs}_{0}^{*}-\mathrm{Abs}_{t}^{*}\right) \times 100
\end{aligned}
$$

where $\mathrm{Abs}_{0}$ and $\mathrm{Abs}_{0}^{*}$ are the absorbance values measured at 0 time of incubation for sample extract and control, respectively. $\mathrm{Abs}_{t}$ and $\mathrm{Abs}_{t}^{*}$ are the absorbance values for sample extract and control, respectively, at $t=120 \mathrm{~min}$.

\section{Laboratory analyses}

Blood samples were collected before (Pre), during (D) and post exercise (PE) every day after each exercise into sterilized tubes. The freshly withdrawn blood was immediately centrifuged at 3,000 rpm for $10 \mathrm{~min}$ and aliquots of serum samples were separated into cryo tubes, and given a coded study identification number. Serum CK activity was assayed without delay and the rest serum samples were shipped frozen for later analysis of LDH, troponin I and hyp.

\section{$C K$ and $L D H$ activities}

Serum CK was measured by a standardized commercially available enzymatic assay (Granutest 15, Merck, Darmstadt, Germany), and LDH activity was measured by UV method, provided with Randox Laboratories, Antrim, UK. 
Troponin I and Hyp assay

Serum troponin I concentration was measured by enzymatic immunoassay technique (EIA) using a sandwich human ELISA kit (Biovendor Research and Diagnostic Co, Cat. No.: RLF-EK0128R, LLC, Asheville, NC 28806, USA). Serum hydroxyproline was measured using commercially available colorimetric assay kit (Catalog \#K555-100; BioVision Incorporated, Milpitas, CA, USA). The assay was performed according to manufacturer's instructions.

\section{Total antioxidant capacity (TAC)}

Colorimetric assay kit (Catalog \#K274-100; BioVision Incorporated, Milpitas, CA, USA) was used to evaluate TAC in the serum of participants. The antioxidant equivalent concentrations were measured at $570 \mathrm{~nm}$ as a function of Trolox concentration according to manufacturer's instructions

$$
\mathrm{Sa} / \mathrm{Sv}=\mathrm{nmol} / \mu \mathrm{l} \text { or } \mathrm{mM} \text { Trolox equivalent }
$$

where $\mathrm{Sa}$ is the sample amount (in nmol) read from the standard curve and $\mathrm{Sv}$ is the undiluted sample volume added to the wells.

\section{Statistical analysis}

A package of SPSS version 16 for windows (SPSS, Chicago, IL, USA) was used for statistical analysis. The data obtained were expressed as mean \pm standard deviation. VAS pain scores, conviction and tendency to use the drink again were analyzed using [3 (time) $\times 2$ (drink)] mixed-effects regression and independent samples $t$-tests, respectively. The change in the variables of muscle fatigue was analyzed using one-way ANOVA followed by post hoc test (Tukey test). The data were statistically significant at $p<0.05$.

\section{Results}

Of the 40 participants enrolled in this study, only 20 participants were assigned sumac juice (twice/day) and 20 were assigned the placebo drink. All subjects performed a regular exercise training for 7 days per week for 1 month. No difference was detected between groups for any of the outcomes listed $(p>0.05)$ (Table I).

Daily nutrient intake showed variation in total calorie, macronutrient and micronutrient intakes of both placebo and sumac groups. However, these parameters are situated in the recommended interval of RDIs as shown in Table II. Also, it showed no effect on the data of muscle fatigue markers in baseline period (pre-exercise test period) (Table VI).

\section{Free radical scavenging and antioxidant activity of sumac extract}

The antioxidant activity of the sumac was investigated in vitro and evaluated according to the inhibition of linoleic acid oxidation and DPPH radical scavenging activity. Sumac extract proved to have a radical scavenging activity of $68.7 \%$ and $87.9 \%$ particularly at the highest concentrations of 500 and $1,000 \mu \mathrm{g} / \mathrm{ml}$, respectively. Also, the same extract had an antioxidant activity with a mean value of $68.7 \%$ regarding to the $\beta$-carotene bleaching rate of sumac extract (Table III).

In the same manner, participants whose diet was supplemented with sumac juice along with exercise showed significant increase in the TAC compared to the placebo exercised group during- and post-exercise training periods (Fig. 1). 
Table II. Dietary record of the subjects (mean \pm standard deviation)

\begin{tabular}{|l|c|c|c|}
\hline \multicolumn{1}{|c|}{ Variable } & Placebo & Sumac & $\begin{array}{c}\text { Reference dietary } \\
\text { intake (RDI) }\end{array}$ \\
\hline Kilocalorie & $2,850 \pm 450$ & $2,420 \pm 527$ & $2,300-3,450$ \\
\hline Carbohydrate $(\mathrm{g})$ & $432.1(144.0)$ & $432.1(144.0)$ & $400-500$ \\
\hline Proteins $(\mathrm{g})$ & $104 \pm 11.0$ & $89 \pm 9.0$ & $70-110$ \\
\hline Fats $(\mathrm{g})$ & $125 \pm 12.5$ & $117 \pm 10.4$ & $100-140$ \\
\hline Carbohydrate $(\%)$ & $54.9 \pm 9.2$ & $48.3 \pm 7.1$ & $45-65 \%$ \\
\hline Proteins $(\%)$ & $15.6 \pm 3.1$ & $12.6 \pm 4.1$ & $10-30 \%$ \\
\hline Fats $(\%)$ & $29.7 \pm 3.5$ & $27.4 \pm 2.1$ & $25-35 \%$ \\
\hline Cholesterol $(\mathrm{mg} / \mathrm{d})$ & $360 \pm 185$ & $357 \pm 250$ & $<350$ \\
\hline Vitamin C (mg/d) & $56.7 \pm 18.7$ & $46.3 \pm 12.4$ & $40-70$ \\
\hline Vitamin E (mg/d) & $7.8 \pm 2.5$ & $5.8 \pm 1.7$ & $11-30$ \\
\hline Vitamin A (IU) & $1,650 \pm 267.0$ & $1,230 \pm 156.0$ & $900-3,000$ \\
\hline Folate $(\mu \mathrm{g} / \mathrm{d})$ & $530 \pm 75.0$ & $410 \pm 63.0$ & $400-1,000$ \\
\hline Vitamin B12 $(\mu \mathrm{g} / \mathrm{d})$ & $6.8 \pm 2.5$ & $3.6 \pm 1.8$ & $2-6$ \\
\hline
\end{tabular}

Table III. Free radical scavenging activity and antioxidant activity of sumac extract

\begin{tabular}{|l|c|c|c|c|c|c|}
\hline & \multicolumn{9}{|c|}{ Radical scavenging activity (\%) } & $\begin{array}{c}\text { Total } \\
\text { antioxidant } \\
\text { activity (\%) }\end{array}$ \\
\hline & \multicolumn{7}{|c|}{ Plant spices } & $\mathbf{5 0}$ & $\mathbf{1 0 0}(\mu \mathrm{g} / \mathbf{m l})$ & $\mathbf{5 0 0}$ & $\mathbf{1 , 0 0 0}$ & $\mathbf{1 , 0 0 0}(\mu \mathrm{g} / \mathbf{m l})$ \\
\hline Sumac extract & 13.9 & 34.5 & 52.3 & 68.7 & 87.9 & 68.7 \\
\hline Ascorbic acid & 19.1 & 85.8 & 92.3 & 95.0 & 94.8 & - \\
\hline Rutin & & & & & & 91.8 \\
\hline
\end{tabular}

Table IV. Mean pain scores (VAS) at three time points [Pre, during (D) and post-exercise (PE) of participants $($ mean $\pm \mathrm{SD})]$

\begin{tabular}{|l|c|c|c|}
\hline \multicolumn{1}{|c|}{ Groups } & Pre (0 week) & During (2 weeks) & PE (4 weeks) \\
\hline Placebo & $8.6 \pm 7.9$ & $13.4 \pm 5.2^{*}$ & $56.3 \pm 20.5^{* *}$ \\
\hline Sumac juice & $10.2 \pm 8.9$ & $9.6 \pm 6.4^{*}$ & $24.1 \pm 10.6^{* *}$ \\
\hline
\end{tabular}

Between groups: $* p<0.05 ; * * p<0.001$ 


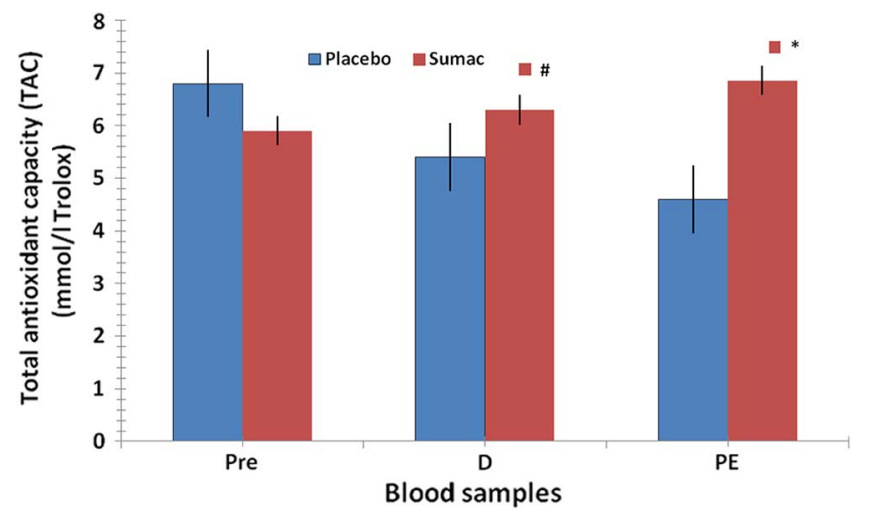

Fig. 1. The level of total antioxidant capacity (TAC) at pre(Pre), during- (D) and postexercise (PE) of adult human participants (mean $\pm \mathrm{SD}$ ). * Significant difference $(p<0.05)$ between the sumac group and the placebo group in Pre. "Significant difference $(p<0.05)$ between sumac group and exercise group in $\mathrm{D}$

Pain (VAS) of participants at pre-, during-and post-exercise

Participants of both sumac and placebo groups showed no change or difference in the mean VAS scores $(p=0.42)$ at pre-exercise period $(0$ week). At the same time, more pain scores were reported in both sumac and placebo groups during the exercise test ( 2 weeks) and after completing the exercise interventions (4 weeks). However, participants treated with sumac juice for 4 weeks showed significant decrease in pain scores during exercise $(p<0.05)$ and after completing exercise test (post-exercise; $p<0.001$ ) compared to those who received placebo drink (Table IV).

\section{Participant satisfaction}

As shown in Table V, participants who received sumac juice supplements reported a higher tendency to use the drink again $(p<0.001)$, a higher overall conviction of the drink $(p<0.001)$ and a higher conviction in the pain reduction they attributed to the drink $(p<0.001)$.

\section{Muscle fatigue biomarkers}

There were significant differences $(p<0.05)$ in muscle fatigue biomarkers among blood samples of placebo and sumac juice groups, being elevated at D and PE vs. Pre values in the

Table V. Participant satisfaction with drink

\begin{tabular}{|c|c|c|c|}
\hline Measure & Groups & Mean score & $p$ \\
\hline \multirow{2}{*}{$\begin{array}{l}\text { Willingness to use drink in } \\
\text { future }(1=\text { very } \\
\text { unwilling; } 10=\text { very } \\
\text { willing) }\end{array}$} & Placebo & $5.7 \pm 2.8$ & \multirow[t]{2}{*}{$<0.001$} \\
\hline & Sumac juice & $9.8 \pm 1.5$ & \\
\hline \multirow{2}{*}{$\begin{array}{l}\text { Drink satisfaction - pain } \\
\text { relief }(1=\text { very satisfied; } \\
5=\text { very dissatisfied })\end{array}$} & Placebo & $4.0 \pm 1.2$ & \multirow[t]{2}{*}{$<0.001$} \\
\hline & Sumac juice & $2.9 \pm 0.8$ & \\
\hline \multirow{2}{*}{$\begin{array}{l}\text { Drink satisfaction - } \\
\text { overall }(1=\text { very } \\
\text { satisfied; } 5=\text { very } \\
\text { dissatisfied })\end{array}$} & Placebo & $3.9 \pm 0.9$ & \multirow[t]{2}{*}{$<0.001$} \\
\hline & Sumac juice & $2.8 \pm 0.6$ & \\
\hline
\end{tabular}


Table VI. Change in muscle fatigue biomarkers at three time points [Pre, during (D) and post exercise $(\mathrm{PE})$ of participants (mean $\pm \mathrm{SD})]$

\begin{tabular}{|l|c|c|c|c|c|c|}
\hline \multicolumn{1}{|c|}{ Parameters } & \multicolumn{2}{c|}{ Pre (0 week) } & \multicolumn{2}{c|}{ During (2 weeks) } & \multicolumn{2}{c|}{ PE (4 weeks) } \\
\hline & Placebo & Sumac juice & Placebo & Sumac juice & Placebo & Sumac juice \\
\hline $\begin{array}{l}\text { Creatine } \\
\text { kinase (IU/1) }\end{array}$ & $267.7 \pm 2.5$ & $280.7 \pm 11.2$ & $288.9 \pm 3.7$ & $251.93 \pm 8.5^{*}$ & $309.97 \pm 7.9$ & $197.6 \pm 5.4^{* *}$ \\
\hline $\begin{array}{c}\text { Lactic acid } \\
\text { dehydrogenase } \\
\text { (IU/l) }\end{array}$ & $37.18 \pm 5.9$ & $42.7 \pm 4.2$ & $45.9 \pm 8.1$ & $32.4 \pm 3.7^{*}$ & $58.3 \pm 11.6$ & $25.7 \pm 2.85^{* *}$ \\
\hline \begin{tabular}{c} 
Troponin I (ng/ml) \\
\hline $\begin{array}{l}\text { Hydroxyproline } \\
\text { (ng/ml) }\end{array}$
\end{tabular} & $0.274 \pm 0.12$ & $0.75 \pm 0.45$ & $1.17 \pm 0.16$ & $0.56 \pm 0.06^{*}$ & $1.9 \pm 0.18$ & $0.38 \pm 0.04^{* *}$ \\
\hline
\end{tabular}

Between groups: ${ }^{*} p<0.05 ; * * p<0.001$

placebo group and significant decrease $(p<0.05)$ in the values of these markers in the sumac juice group at D and PE vs. pre-exercise (Table V). CK activity was significantly decreased $(p<0.05)$ in the sumac group at $\mathrm{D}$ and $\mathrm{PE}(251.93 \pm 23.2$ and $197.6 \pm 23.19 \mathrm{IU} / \mathrm{L}$, respectively) vs. D and PE of the placebo group $(288.9 \pm 26.13$ and $309.97 \pm 23.3 \mathrm{IU} / \mathrm{L}$, respectively). Also, the LDH activity was significantly decreased $(p<0.05)$ in the sumac group at $\mathrm{D}$ and $\mathrm{PE}(32.4 \pm 5.2$ and $25.7 \pm 4.6 \mathrm{IU} / \mathrm{L}$, respectively) vs. $\mathrm{D}$ and $\mathrm{PE}$ of the placebo group $(45.9 \pm 9.6$ and $58.3 \pm 10.3 \mathrm{IU} / \mathrm{L}$, respectively). Whereas, troponin I concentrations were significantly decreased $(p<0.05)$ in the sumac group at D and PE $(0.56 \pm 0.23$ and $0.38 \pm 0.21 \mathrm{ng} / \mathrm{ml}$, respectively) vs. D and PE of the placebo group $(1.17 \pm 0.69$ and $1.9 \pm$ $0.9 \mathrm{ng} / \mathrm{ml}$, respectively). Hyp values, shown in Table VI, were decreased $(p<0.05)$ in the sumac group at D and PE $(0.68 \pm 0.25$ and $0.51 \pm 0.19 \mathrm{ng} / \mathrm{ml}$, respectively $)$ vs. D and PE of the placebo group $(2.5 \pm 0.62$ and $3.9 \pm 0.98 \mathrm{ng} / \mathrm{ml}$, respectively $)$.

\section{Discussion}

Regular physical activity associated with a balanced diet is known as an important factor for health. However, exhaustive and/or intense physical activity can induce diseases, acute inflammation, injuries and chronic fatigue $(7,9,44)$, and that the excessive muscle-skeletal stress associated with intensive physical exercise is a response to overtraining, inducing acute local inflammation (15). It is expected, therefore, that training exercise programs will experience inflammation and pain as result of free radicals production (16). The main target of this study was the specific effect of sumac juice drink on muscle indices and physical muscle performance during an acute, intense exercise for 4 weeks. Therefore, the identification of common dietary substances of natural plant origin capable of affording beneficial protection or modulating muscle fatigue may have important health implications (59).

In this study before studying the improvement activity of sumac juice on muscle fatigue, free radical scavenging and antioxidant activities of sumac extracts were estimated.

In this study, sumac showed a considerable antioxidative activity when it was subjected to in vitro antioxidant analysis using both DPPH and $\beta$-carotene tests. The data obtained suggest that the antioxidant activity of sumac extract against free radical oxidative stress and 
lipid peroxidation mechanisms may be related to the presence of tocopherols and other unknown antioxidant components as well as unsaturated fatty acids $(5,24,36)$.

Previously, it was reported that overtraining syndrome produces diseases, acute inflammation, injuries and chronic muscle fatigue via oxidative free radical mechanism which may produce a partial toxicity during exercise programs of varying intensities $(9,34,38,42)$.

In the current study, more pain was reported in the participants of both sumac and placebo treated groups following exercise interventions for 4 weeks. However, in participants treated with sumac juice twice daily for 4 weeks, significant decrease in pain score was reported compared to that of the placebo group. The reduction in pain scores in the sumac treated group supports that sumac may have a potential protective role against acute muscle pain exerted following exhausted exercise programs.

Previous studies reported that oxidative tissue damage is considered one of the most important factors of acute muscle injury with subsequent release of pain scores. Whereas the oxidative tissue damage activates muscle tissues for the inflammatory response and excessive production of oxidative free radicals which increase secondary muscle soreness $(19,28)$. So, nutritional antioxidants of plant origin have been suggested as an alternative treating strategy for ameliorating muscle pain and soreness following exercise or exhausted overtraining (8).

Previously, it was reported that sumac contains antioxidants, flavonoids and hydrolyzable tannins which have anticancer, anti-tumor and hypoglycemic properties $(5,24,36)$. Therefore, the reduction in pain score among participants treated with sumac juice may be due to the antioxidant effects of anthocyanins of such plants, through inhibition of nitrite peroxide and isoform of nitric oxide synthase (iNOS) that leads to oxidative damage produced by different cell cytokines during inflammatory stress $(10,13)$. Most studies reported the release of intramuscular enzymes into blood and its significance as pivotal indicators for skeletal muscle damage $(10,38)$, especially the occurrence of enzyme efflux in response to overtraining as in unusual eccentric work or long duration strenuous exercise $(38,42,60,61)$.

Also, it has been thought that higher tension may produce a considerable mechanical damage to the muscle fibrils which in turn allows the efflux of enzymes such as CK and LDH into the blood. These enzymes are considered as good markers for skeletal muscle damage $(6,42)$.

In our study, a significant decrease (enhancement) was reported in the levels of both CK and LDH in participants who receive sumac juice supplementation twice daily for 4 weeks compared to the placebo group which showed significant increase in skeletal muscle enzymes during exercise and in post-exercise intervals. The improvement in skeletal muscle enzymes may be related to natural antioxidants' presence in sumac juice (24). Consumption of about $225 \mathrm{mg}$ sumac extract/300 ml sumac juice per day provides significant reduction in the levels of the circulated inflammatory markers of healthy subjects. The data obtained matched with other researchers' results who reported a decrement in serum inflammatory markers including $\mathrm{C}$ reactive protein (CRP) by $25 \%$ after 28 days $(8,14,19,21,23,26)$. The potential of skeletal troponin I and hyp as markers of muscle injury may be useful for assessing the effects of intense exercise for soft tissue injuries $(31,48,51,55)$. So, in our study, troponin I and hyp values were measured in the serum of placebo and sumac groups' pre, during and post-exercise test. The data obtained showed a significant increase in the placebo group compared to the sumac group which showed a significant enhancement in the levels of troponin I and hyp.

Most of the studies have shown that normal physical activity, basketball training and a treadmill exercise training test can also lead to a troponin and hyp rise in healthy individuals. 
The presence of hydroxyproline amino acids and troponin I in the serum is the result of collagen fiber degradation either by overuse or strained muscle damage $(30,45,46,49,51)$. However, in sumac juice group, the data obtained indicated that treatment with sumac juice could enhance protein collagen and troponin I levels in skeletal muscle. This may be related to the antioxidant and anti-inflammatory activity of sumac phenolic constituents $(24,36)$.

In our study, a significant increase (enhancement) in the TAC in the sumac juice group receiving the juice twice a day for 30 days compared to the placebo group which showed significant reduction in TAC activity. This may be related to the antioxidant and free radical scavenging activity of sumac constituents which protect the body against the harmful effects of free radicals produced from exercise $(24,27)$. Although the VAS has consistent and welldefined clinically meaningful thresholds in the assessment of acute levels of pain $(12,25,27$, 42 ), the only methodological limitation of our study was the subjective assessment of pain scores by VAS.

In conclusion, the data obtained showed that administration of sumac juice for 30 days induced a significant reduction in muscle fatigue and pain, and enhanced muscle performance among healthy subjects following vigorous exercise interventions. Also, the data showed significant enhancement in the level of serum biomarkers; CK, LDH, troponin I and hyp which indicates a beneficial effect of oral administration of sumac juice on muscle performance among athletes. Further research is needed to examine the mechanism by which the sumac can improve collagen fiber degradation.

\section{Acknowledgement}

The authors would like to extend their sincere appreciation to the Deanship of Scientific Research at King Saud University for funding this research through the research group no. RGP-VPP-209.

\section{REFERENCES}

1. Askari G, Ghiasvand R, Feizi A, Ghanadian SM, Karimian J: The effect of quercetin supplementation on selected markers of inflammation and oxidative stress. J. Res. Med. Sci. 17, 637-641 (2012)

2. Aounallah-Skhiri H, Traissac P, El Ati J, Eymard-Duvernay S, Landais E, Achour N, Delpeuch F, Ben Romdhane H, Maire B: Nutrition transition among adolescents of a south-Mediterranean country: dietary patterns, association with socio-economic factors, overweight and blood pressure. A cross-sectional study in Tunisia. Nutr. J. 10, 38 (2011)

3. Bijur PE, Silver W, Gallagher EJ: Reliability of the visual analog scale for measurement of acute pain. Acad. Emerg. Med. 8, 1153-1157 (2001)

4. Boyas S, Guével A: Neuromuscular fatigue in healthy muscle: underlying factors and adaptation mechanisms. Ann. Phys. Rehabil. Med. 54, 88-108 (2001)

5. Brand WW, Cuvelier HE, Berset C: Use of a free radical method to evaluate antioxidant activity. Food Sci. Technol. 82, 25-30 (1995)

6. Candan F, Sokmen A: Effects of Rhus coriaria L. (Anacardiaceae) on lipid peroxidation and free radical scavenging activity. Phytother. Res. 18, 84-86 (2004)

7. Cazorla G, Petibois C, Bosquet L: Lactate et exercice: mythes et réalités. (Lactate and exercise: myths and realities). Rev. Sci. Tech. Activ. Phys. Sport (Grenoble) 22, 63-76 (2001)

8. Clarkson PM, Hubal MJ: Exercise-induced muscle damage in humans. Am. J. Phys. Med. Rehabil. 81, S52-S69 (2002)

9. Connolly DA, McHugh MP, Padilla-Zakour OI, Carlson L, Sayers SP: Efficacy of a tart cherry juice blend in preventing the symptoms of muscle damage. Br. J. Sports Med. 40, 679-683 (2006)

10. Cooper CE, Vollaard NBJ, Choueiri T, Wilson MT: Exercise, free radicals and oxidative stress. Biochem. Soc. Trans. 30, 280-285 (2002) 
11. Evans WJ, Meredith CN, Cannon JG, Dinarello CA, Frontera WR, Hughes VA, Jones BH, Knuttgen HG: Metabolic changes following eccentric exercise in trained and untrained men. J. Appl. Physiol. 61, 1864-1868 (1986)

12. Friden J, Seger J, Ekblom B: Sublethal muscle fibre injuries after high-tension anaerobic exercise. Eur. J. Appl. Physiol. 57, 360-368 (1988)

13. Gallagher EJ, Liebman M, Bijur PE: Prospective validation of clinically important changes in pain severity measured on a visual analog scale. Ann. Emerg. Med. 38, 633-638 (2001)

14. Ghyasi R, Sepehri G, Mohammadi M, Badalzadeh R, Ghyasi A: Effect of mebudipine on oxidative stress and lipid peroxidation in myocardial ischemic-reperfusion injury in male rat. J. Res. Med. Sci. 17, 1150-1155 (2012)

15. Giusti MM, Wrolstad RE (2001): Characterization and measurement with UV-visible spectroscopy. In: Current Protocols in Food Analytical Chemistry, ed Wrolstad RE, John Wiley \& Sons, New York, pp. 1-13

16. Gleeson M: Biochemical and immunological markers of overtraining. J. Sports Sci. Med. 2, 31-41 (2002)

17. Golden TR, Hinerfeld DA, Melov S: Oxidative stress and aging: beyond correlation. Aging Cell 1, 117-123 (2002)

18. Gorski T, Cadore EL, Pinto SS, da Silva EM, Correa CS, Beltrami FG, Kruel LF: Use of NSAIDs in triathletes: prevalence, level of awareness and reasons for use. Br. J. Sports Med. 45, 85-90 (2011)

19. Gosker HR, Schols AM: Fatigued muscles in COPD but no finishing line in sight. Eur. Respir. J. 31, 693-694 (2008)

20. Hirose L, Nosaka K, Newton M, Laveder A, Kano M, Peake J, Suzuki K: Changes in inflammatory mediators following eccentric exercise of the elbow flexors. Exerc. Immunol. Rev. 10, 75-90 (2004)

21. Howatson G, van Someren KA: The prevention and treatment of exercise-induced muscle damage. Sports Med. 38, 483-503 (2008)

22. Jacob RA, Spinozzi GM, Simon VA, Kelley DS, Prior RL, Hess-Pierce B, Kader AA: Consumption of cherries lowers plasma urate in healthy women. J. Nutr. 133, 1826-1829 (2003)

23. Kadoglou NP, Vrabas IS, Kapelouzou A, Lampropoulos S, Sailer N, Kostakis A, Liapis CD, Angelopoulou N: The impact of aerobic exercise training on novel adipokines, apelin and ghrelin, in patients with type 2 diabetes. Med. Sci. Monit. 18, CR290-CR295 (2012)

24. Karvonen M, Kentala K, Mustala O: The effects of training heart rate: a longitudinal study. Ann. Med. Exp. Biol. Fenn. 35, 307-315 (1957)

25. Kosar M, Bozan B, Temelli F, Baser KHC: Antioxidant activity and phenolic composition of sumac (Rhus coriaria L.) extracts. Food Chem. 103, 952-959 (2006)

26. Kuehl KS, Perrier ET, Elliot DL, Chesnutt JC: Efficacy of tart cherry juice in reducing muscle pain during running: a randomized controlled trial. J. Int. Soc. Sports Nutr. 7, 7-17 (2010)

27. Likert R: A technique for the measurement of attitudes. Arch. Psychol. 140, 1-55 (1932)

28. Mastaloudis A, Leonard SW, Traber MG: Oxidative stress in athletes during extreme endurance exercise. Free Radic. Biol. Med. 31, 911-922 (2001)

29. Miles MP, Andring JM, Pearson SD, Gordon LK, Kasper C, Depner CM, Kidd JR: Diurnal variation, response to eccentric exercise, and association of inflammatory mediators with muscle damage variables. J. Appl. Physiol. 104, 451-458 (2008)

30. Mothana RA: Anti-inflammatory, antinociceptive and antioxidant activities of the endemic Soqotraen Boswellia elongata Balf. f. and Jatropha unicostata Balf. f. in different experimental models. Food Chem. Toxicol. 49, 2594-2599 (2011)

31. Nie J, Tong TK, Shi Q, Lin H, Zhao J, Tian Y: Serum cardiac troponin response in adolescents playing basketball. Int. J. Sports Med. 29, 449-452 (2008)

32. Onuoha GN, Alpar EK, Dean B, Tidman J, Rama D, Laprade M, Pau B: Skeletal troponin-I release in orthopedic and soft tissue injuries. J. Orthop. Sci. 6, 11-15 (2001)

33. Otten JJ, Hellwig JP, Meyers LD (2006): Dietary Reference Intakes: The Essential Guide to Nutrient Requirements. National Academy Press, Washington, DC

34. Ozcan M: Antioxidant activities of rosemary, sage, and sumac extracts and their combinations on stability of natural peanut oil. J. Med. Food 6, 267-270 (2003)

35. Palange P, Ward SA, Carlsen KH, Casaburi R, Gallagher CG, Gosselink R, O’Donnell DE, Puente-Maestu L, Schols AM, Singh S, Whipp BJ: Recommendations on the use of exercise testing in clinical practice. Eur. Respir. J. 29, 185-209 (2007)

36. Papassotiriou I, Alexiou VG, Tsironi M, Skenderi K, Spanos A, Falagas ME: Severe aseptic inflammation caused by long distance running $(246 \mathrm{~km})$ does not increase procalcitonin. Eur. J. Clin. Invest. 38, 276-279 (2008)

37. Pietta P, Simonetti P, Mauri P: Antioxidant activity of selected medicinal plant. J. Agric. Food Chem. 46, 4487-4490 (1998) 
38. Rainoldi A, Gazzoni M, Merletti R, Minetto MA: Mechanical and EMG responses of the vastus lateralis and changes in biochemical variables to isokinetic exercise in endurance and power athletes. J. Sports Sci. 26, 321-331 (2008)

39. Rayne S, Mazza G: Biological activities of extracts from sumac (Rhus spp.): a review. Plant Foods Hum. Nutr. 62, 165-175 (2007)

40. Rodenburg JB, Bär PR, De Boer RW: Relations between muscle soreness and biochemical and functional outcomes of eccentric exercise. J. Appl. Physiol. 74, 2976-2983 (1993)

41. Rondelli RR, Dal Corso S, Simões A, Malaguti C: Methods for the assessment of peripheral muscle fatigue and its energy and metabolic determinants in COPD. J. Bras. Pneumol. 35, 1125-1135 (2009)

42. Saey D, Côté CH, Mador MJ, Laviolette L, LeBlanc P, Jobin J, Maltais F: Assessment of muscle fatigue during exercise in chronic obstructive pulmonary disease. Muscle Nerve 34, 62-71 (2006)

43. Schuback K, Essén-Gustavsson B, Persson SG: Incremental treadmill exercise until onset of fatigue and its relationship to metabolic response and locomotion pattern. Equine Vet. J. 30, 337-341 (1999)

44. Schwane JA, Williams JS, Sloan JH: Effects of training on delayed muscle soreness and serum creatine kinase activity after running. Med. Sci. Sports Exerc. 19, 584-590 (1987)

45. Seeram NP, Bourquin LD, Nair MG: Degradation products of cyanidine glycosides from tart cherries and their bioactivities. J. Agric. Food Chem. 49, 4924-4929 (2001)

46. Serrão FV, Foerster B, Spada S, Morales MM, Monteiro-Pedro V, Tannús A, Salvini TF: Functional changes of human quadriceps muscle injured by eccentric exercise. Braz. J. Med. Biol. Res. 36, 781-786 (2003)

47. Shave R, Baggish A, George K, Wood M, Scharhag J, Whyte G, Gaze D, Thompson PD: Exercise-induced cardiac troponin elevation: evidence, mechanisms, and implications. J. Am. Coll. Cardiol. 56, 169-176 (2010)

48. Shave R, Ross P, Low D, George K, Gaze D: Cardiac troponin I is released following high-intensity shortduration exercise in healthy humans. Int. J. Cardiol. 145, 337-339 (2010)

49. Siegel AJ, Januzzi J, Sluss P, Lee-Lewandrowski E, Wood M, Shirey T, Lewandrowski KB: Cardiac biomarkers, electrolytes, and other analytes in collapsed marathon runners: implications for the evaluation of runners following competition. Am. J. Clin. Pathol. 129, 948-951 (2008)

50. Simpson JA, Labugger R, Hesketh GG, D’Arsigny C, O’Donnell D, Matsumoto N, Collier CP, Iscoe S, Van Eyk JE: Differential detection of skeletal troponin I isoforms in serum of a patient with rhabdomyolysis: markers of muscle injury. Clin. Chem. 48, 1112-1114 (2002)

51. Singleton VJ, Rossi JA: Colorimetry of total phenolics with phosphomolybdic-phosphotungstic acid reagents. Am. J. Enol. Vitic. 16, 144-158 (1965)

52. Spruit MA, Thomeer MJ, Gosselink R, Troosters T, Kasran A, Debrock AJ, Demedts MG, Decramer M: Skeletal muscle weakness in patients with sarcoidosis and its relationship with exercise intolerance and reduced health status. Thorax 60, 32-38 (2005)

53. Stauber WT: Eccentric action of muscles: physiology, injury and adaptation. Exerc. Sport. Sci. Rev. 17, 157-186 (1989)

54. Stendardi L, Grazzini M, Gigliotti F, Lotti P, Scano G: Dyspnea and leg effort during exercise. Respir. Med. 99, 933-942 (2005)

55. Sung PS: Disability and back muscle fatigability changes following two therapeutic exercise interventions in participants with recurrent low back pain. Med. Sci. Monit. 19, 40-48 (2013)

56. Swallow EB, Gosker HR, Ward KA, Moore AJ, Dayer MJ, Hopkinson NS, Schols AM, Moxham J, Polkey MI: A novel technique for nonvolitional assessment of quadriceps muscle endurance in humans. J. Appl. Physiol. 103, 739-746 (2007)

57. Sydney-Smith M, Quigley B (1992): Delayed Onset Muscle Soreness: Evidence of Connective Tissue Damage, Liquid Peroxidation and Altered Renal Function After Exercise. Australian Sports Commission, Canberra

58. Tjora S, Gjestland H, Mordal S, Agewall S: Troponin rise in healthy subjects during exercise test. Int. J. Cardiol. 151, 375-376 (2011)

59. Todd KH, Funk KG, Funk JP, Bonacci R: Clinical significance of reported changes in pain severity. Ann. Emerg. Med. 27, 485-489 (1996)

60. Wang H, Nair MG, Strasburg GM, Chang YC, Booren AM, Gray JI, DeWitt DL: Antioxidant and antiinflammatory activities of anthocyanins and their aglycon, cyanidin, from tart cherries. J. Nat. Prod. 62, 294-296 (1999)

61. Wilmore J, Costill D, Kenney WL (2008): Physiology of Sport and Exercise. Human Kinetics Publishers, Champaign 